\title{
ASSESSMENT OF TIME EFFECTS IN BRICS MARKETS
}

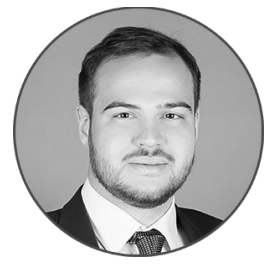

Article history:

Received 7 February 2018

Received in revised form

5 March 2018

Accepted 19 March 2018

Translated 3 September 2018

Available online 28 September 2018

JEL classification: G02, G11, G14, G15

Keywords: stock market, time effect, day-of-the-week effect, month-of-the-year effect, quarter-of-the-year effect

\section{Sergei V. VATRUSHKIN}

National Research University Higher School of Economics (NRU HSE), Moscow, Russian Federation

VSV001@ya.ru

https://orcid.org/0000-0003-1993-2839

\begin{abstract}
Importance This article considers and discusses the issues related to the determination of temporal effects on the securities markets of the BRICS nations.

Objectives The article aims to identify temporal effects on the stock markets of the BRICS countries, as well as determine the efficiency of these markets, and provide practical recommendations for increasing the yield of the securities portfolio.

Methods For the study, I used the regression and econometric analyses approaches applying the Microsoft Excel and Gretl software.

Results The article presents certain results of identification and evaluation of five temporal effects on the stock markets of the BRICS countries, as well as it determines the efficiency of these markets. Also, it submits practical recommendations to increase the yield of the investment portfolio. The revealed temporal effects testify to the inefficiency of the stock markets and assume the possibility to derive excess return if they are taken into account when building a trade strategy.

Conclusions and Relevance For a number of the indexes considered, temporal effects are typical. This contradicts the efficient-market hypothesis, according to which the financial asset quotes get formed independently, which does not allow to draw an excess yield.
\end{abstract}

The editor-in-charge of this article was Irina M. Vechkanova

Authorized translation by Andrey V. Bazhanov

\section{Introduction}

The leading hypothesis of pricing on stock markets is the Efficient-Market Hypothesis by Eugene F. Fama [1]. According to this hypothesis, there are three forms of market efficiency.

- Weak Form Efficiency. The value of the asset reflects all past information regarding the asset.

\footnotetext{
* This present article discusses further the subject of the article published previously: Vatrushkin S.V. Evaluation of the Month-of-theYear Effect on the Securities Markets of the BRICS Nations. Digest Finance, 2018, vol. 23, iss. 2, pp. 172-181. URL: https://doi.org/10.24891/df.23.2.172

${ }^{\dagger}$ For the source article, please refer to: Ватрушкин С.В. Оценка временных эффектов на рынках стран БРИКС. Финансы и кредит. 2018. T. 24. № 4. C. 913-928. URL: https://doi.org/10.24891/fc.24.4.913
}

- Semi-Strong Form Efficiency. The value of the asset reflects past information plus all available public information.

- Strong Form Efficiency. The value of the asset reflects all the information: past, public, and the insider one.

Considering the given classification, it is clear that it is not possible to build a trading strategy with profitability surpassing the market profitability on the strong form securities market, as all information is already reflected in prices.

However, in practice, repeated quote movements were found, depending on a certain period of time, which were later called Temporal Effects. Their 
existence testifies to the weak form of the stock market efficiency, and it potentially allows to derive excess return.

This article discusses the five most common temporal effects: the Day-of-the-Week effect, Turn-ofthe-Month effect, Month-of-the-Year effect, Quarter-ofthe-Year effect (Santa Claus rally effect), and the Quarter-End effect.

The objective of deriving additional profits when setting-up the investment portfolio of securities is a priority for each portfolio manager. The trader builds a trading strategy taking into account his own idea of pricing on the securities market. Therefore, the issue of the possibility of using the knowledge obtained in the field of temporal effects to increase the overall portfolio yield without changing its risk is acute.

Moreover, in terms of expanding the area of scientific knowledge, a clear understanding of the temporal effects and their stability provides an opportunity to determine the market efficiency of each particular stock market.

Based on the results obtained, I am going to form an efficiency rating of the BRICS nations' stock markets. This will help expand the area of scientific knowledge, and it also makes possible to apply it in practice and theory terms in related areas.

\section{The Month-of-the-Year Effect Study Coverage}

This article discusses the temporal effects that are attributed to the so-called cyclic class when the prices of financial assets depend on a certain period of time. In particular, the results are presented on the following:

- Day-of-the-Week effect. It indicates a dispersion of financial asset prices depending on the day of the week. The varieties of this effect are the Monday effect (securities market returns on Mondays are less than the other days of the week), the Weekend effect (stocks exhibit abnormally large returns at the end of the week), the Friday effect (stocks exhibit abnormally large returns on Fridays compared to those on the other days of the week), etc.

- Turn-of-the-Month (TOM) effect. According to this effect, it is revealed that the stocks returns in the last days of the month are higher than in the first days.

- Month-of-the-Year effect. It indicates a dispersion of financial asset prices depending on the month of the year. The most common type is the January effect, which suggests an abnormally high yield in January compared to other months.

- Quarter-of-the-Year effect (Santa Claus rally effect). It indicates a dispersion of stocks returns depending on the quarter of the year. If the yield in the fourth quarter is higher than the yields in all the previous ones, the phenomenon is called the Santa Claus rally effect.

- Quarter-End effect. It indicates a dispersion of stocks returns within the quarter, namely, that the returns at the end of the quarter are higher than the other quarter periods.

The Efficient-Market Hypothesis is the object of great attention in the world scientific community, and it is fundamental in determining the fair value of assets. According to the theory by Louis Bachelier [2] underlying the definition of the three forms of market efficiency formulated by Eugene F. Fama, the prices get formed in much the same manner as random walking and take into account all the information available on the market.

In 1980, Kenneth R. French introduced the concept of Monday effect on the U.S. stock market for the first time, studying the Standard \& Poor's 500 for the period from 1953 to 1977 (6,024 observations) [3].

He suggested that the stock returns, calculated on the basis of close-to-close prices, should stay consistent throughout all trading days of the week according to the price random-walk hypothesis. So two assumptions are made.

1. Stock returns are generated only during active trading and the expected return is the same for each day of the week.

2. It is necessary to take into account the weekend accumulated returns and respectively, the expected return for Monday should be three times the expected return for other days of the week.

However, the results obtained rejected both the assumptions. It turned out that the average stock 
return for Monday was significantly negative. This phenomenon was called the Monday effect.

This finding evoked a wide response. R.J. Rogalski [4], L. Harris [5], R.A. Ariel [6], J. Lakonishok and S. Smidt [7], G.N. Pettengill and B.D. Jordan [8], K. Liano and J.T. Lindley [9], S.P. Keef and M.L. Roush [10] conduct additional studies, which confirm the inconsistency of returns depending on a certain period of time (day, week, month, year).

Moreover, similar temporal effects are found by J. Jaffe and R. Westerfield for the stock markets of Europe [11], R. Aggarwal and P. Rivoli for the stock markets of Asia [12], G.E. Marrett and A. Worthington for Australia [13], D. Mbululu and C. Chipeta for South Africa [14]. In Russia, the study of temporal effects was done by M. Kurashinov [15], C.B. McGowan and I. Ibrihim [16].

In addition, J.C. Singleton and J.R. Wingender confirm the existence of calendar anomalies for debt instruments [17], J.S. Thatcher and L.P. Blenman - for currencies markets [18], K. Liano, G.-C. Huang and B.E. Gup - for OTC markets [19], E.T. Johnston, W.A. Kracaw and J.J. McConnell - for derivatives markets [20], and A.L. Redman, H. Manakyan, K. Liano - for fiscal asset markets [21].

Different authors explain the reasons for the existence of temporal effects in the following way: R.W. Sias and L.T. Starks say of the irrational behavior of individual investors [22]; A. Abraham and D.L. Ikenberry say of the stock market freeze [23]; A. Damodaran says of the non-uniform spread of information releases [24]; G.N. Pettengill, J.R. Wingender and R. Kohli say of the microeffects [25]; and G.N. Pettengill says of the psycho-behavioral models of actions of individual investors [26].

A number of publications are considering the possibility of deriving excess return from temporal effects, such as the articles by E.H. Chow, P. Hsiao and M.E. Solt [27], and E.M. Miller, L.J. Prather and M.I. Mazumder [28].

However, there are no studies on the cross-country analysis of temporal effects on the stock markets of the BRICS nations. Neither there is any BRICS stock exchange efficiency rating on the basis of the obtained results.

\section{The Investigated Data}

As the data for study, we take the values of the indexes of IBOV, MICEX, RTS, SENSEX, NIFTY, HSI, SHCOMP, and TOP40, which are the major market ones for the Brazilian Stock Exchange (BM \& FBOVESPA), the Russian Exchange (PAO Moskovskaya Birzha - Moscow Exchange), Bombay Stock Exchange Ltd. (BSE), National Stock Exchange of India Limited (NSE), Hong Kong Exchanges and Clearing Limited (HKEx), Shanghai Stock Exchange (SSE), and the Johannesburg Stock Exchange Limited (JSE Limited). Thus, all the stock markets of the BRICS nations are under consideration.

Simultaneous considering of several trading floors within the framework of portfolio set-up helps diversify risk, and also take into account the peculiarities of formation of the Turn-of-the-Month effect for each particular country.

In order to determine the stability of the considered temporal effect for each country, the total sample is divided into five-year sub-periods. All the data taken cover the period from the beginning of data publication till June 30, 2015. Fig. 1 shows the periods of study of each particular index as a time axis.

\section{The Research Methodology}

The GARCH $(1,1)$ model (which stands for Generalized Autoregressive Conditional Heteroscedasticity), first developed by Tim Bollerslev (1986) ${ }^{1}$, is used as the principal one. It helps determine temporal effects and take into account autocorrelation and heteroscedasticity peculiar for time series of stock indexes.

Using the other two models with conditional heteroscedasticity GRJ-GARCH (or TGARCH) developed by Lawrence R. Glosten, Ravi Jagannathan and David E. Runkle ${ }^{2}$, and EGARCH developed by Daniel B. Nelson ${ }^{3}$ is inexpedient, as it was confirmed

\footnotetext{
${ }^{1}$ Bollerslev T. Generalized Autoregressive Conditional Heteroskedasticity. Journal of Econometrics, 1986, vol. 31, iss. 3, pp. 307-327. URL: http://citeseerx.ist.psu.edu/viewdoc/download? doi=10.1.1.468.2892\&rep=rep1\&type=pdf

${ }^{2}$ Glosten L.R., Jagannathan R., Runkle D.E. On the Relation between the Expected Value and the Volatility of the Nominal Excess Returns on Stocks. The Journal of Finance, 1993, vol. 48, no. 5, pp. 1779-1801. URL: https://faculty.washington.edu/ezivot/econ589/GJRJOF1993.pdf

${ }^{3}$ Nelson D.B. Conditional Heteroskedasticity in Asset Returns: A New Approach. Econometrica, 1991, vol. 59, no. 2, pp. 347-370. URL: https://doi.org/10.2307/2938260
} 
by Elena A. Fedorova and Evgenii V. Gilenko [29], because the factors that are responsible for the effect of negative values of the previous series are insignificant.

The index yield is a dependent variable, which gets calculated by the following formula

$$
R_{t}=\ln \left(I_{t} / I_{t-1}\right) \cdot 100 \text {, }
$$

where $R_{t}$ is the index yield on day $\mathrm{t}$, calculated as a yield in logarithmic form from the previous trading day closing to the current trading day closing;

$I_{t}$ is the $l$-index value at-the-close of day $t$;

$I_{t-1}$ is the $l$-index value at-the-close of day $t-1$.

When considering the Day-of-the-Week effect, the values of daily yields are used as independent variables.

$$
\begin{aligned}
& R_{t}=D_{M o} R_{M o}+D_{T u} R_{T u}+D_{W e} R_{W e}+D_{T h} R_{T h}+ \\
& +D_{F r} R_{F r}+\varphi R_{(t-1)}+\epsilon_{t},
\end{aligned}
$$

where $D_{M o} \ldots D_{F r}$ is the daily dummy variable equal to 1 , if the day falls on the studied day, and 0 , if otherwise;

\section{$R_{M 0} \ldots R_{F r}$ are the regression coefficients;}

$R_{t-1}$ is the index yield on the previous trading day;

$\varphi$ is the time series autocorrelation factor.

The model removes the constant in order to avoid full multicollinearity, for if maintaining it, the sum of the dummy variables would be equal to the constant. That would be a question of linear dependence of regressors.

The hypothesis on equality of coefficients on each day of the week is tested (constant return is independent from the day of the week).

When considering the Turn-of-the-Month effect, the values of yields of the first and last nine trading days of the month are used as independent variables.

$$
\begin{aligned}
& R_{t}=\text { const }+D_{1} R_{1}+D_{2} R_{2}+D_{3} R_{3}+D_{4} R_{4}+D_{5} R_{5}+ \\
& +D_{6} R_{6}+D_{7} R_{7}+D_{8} R_{8}+D_{9} R_{9}+D_{-9} R_{-9}+ \\
& +D_{-8} R_{-8}+D_{-7} R_{-7}+D_{-6} R_{-6}+D_{-5} R_{-5}+ \\
& +D_{-4} R_{-4}+D_{-3} R_{-3}+D_{-2} R_{-2}+D_{-1} R_{-1}+\varepsilon_{t},
\end{aligned}
$$

where $D_{1} \ldots D_{9}$ is the first-to-ninth-trading-day-at-thebeginning-of-the-month dummy variable equal to 1 , if the day falls on the studied day, and 0 , if otherwise;
$D_{-9} . . . D_{-1}$ is the ninth-to-first-trading-day-at-the-end-ofthe-month dummy variable equal to 1 , if the day falls on the studied day, and 0 , if otherwise;

$R_{1} \ldots R_{-1}$ are the regression coefficients.

If the null hypothesis on equality of coefficients regardless of the beginning or end of the month is rejected, then there is a yield dispersion, which indicates the existence of the Turn-of-the-Month effect.

The GARCH model for determining the Month-of-theYear effect is as follows:

$$
\begin{aligned}
& R_{t}=D_{\mathrm{Ian}} R_{\mathrm{Jan}}+D_{\mathrm{Feb}} R_{\mathrm{Feb}}+D_{\mathrm{Mar}} R_{\mathrm{Mar}}+ \\
& +D_{\mathrm{Apr}} R_{\mathrm{Apr}}+D_{\mathrm{May}} R_{\mathrm{May}}+D_{\text {Iun }} R_{\mathrm{Jul}}+ \\
& +D_{\mathrm{Aug}} R_{\mathrm{Aug}}+D_{\mathrm{Sep}} R_{\mathrm{Sep}}+D_{\mathrm{Oct}} R_{\mathrm{Oct}}+ \\
& +D_{\mathrm{Nov}} R_{\mathrm{Nov}}+D_{\mathrm{Dec}} R_{\mathrm{Dec}}+\varepsilon_{t},
\end{aligned}
$$

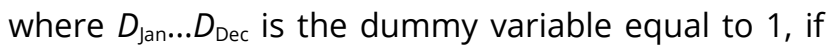
the yield on the studied day falls on a certain month of the year, and 0, if otherwise;

$R_{\text {Jan } \ldots} . R_{\text {Dec }}$ are the regression coefficients.

The constant is also removed in the model. If the null hypothesis on equality of regression coefficients deviates in each of the months, the existence of the Month-of-the-Year effect can be asserted.

When considering the Santa Claus rally effect, the values of yields of one of the quarters of the year are used as independent variables.

$$
\begin{aligned}
& R_{t}=D_{Q 1} R_{Q 1}+D_{Q 2} R_{Q 2}+D_{Q 3} R_{Q 3}+ \\
& +D_{Q 4} R_{Q 4}+\varepsilon_{t},
\end{aligned}
$$

where $D_{Q_{1} \ldots D_{Q 4}}$ is the dummy variable equal to 1 , if the yield on the studied day falls on a certain quarter of the year, and 0, if otherwise;

$R_{Q 1} \ldots R_{Q 4}$ are the regression coefficients.

The null hypothesis on equality of coefficients (constant return is independent from the quarter of the year).

When considering the Quarter-End effect, the values of yields of one of the six periods of the quarter (two periods per month) are used as independent variables. This can be presented as follows:

$$
\begin{aligned}
& R_{t}=D_{P 1} R_{P 1}+D_{P 2} R_{P 2}+D_{P 3} R_{P 3}+D_{P 4} R_{P 4}+ \\
& +D_{P 5} R_{P 5}+D_{P 6} R_{P 6}+\varepsilon_{t},
\end{aligned}
$$


where $D_{P 1} \ldots D_{P 6}$ is the one-of-the-six-periods-of-thequarter dummy variable equal to 1 , if the day yield falls on the studied period, and 0 , if otherwise;

$R_{P 1} \ldots R_{P 6}$ are the regression coefficients.

If the null hypothesis on equality of coefficients is rejected, then there is a yield dispersion in each particular period of the quarter. This indicates the existence of the temporal effect within the quarter.

Thus, based on the collected information and to estimate each of the five temporal effects, I have constructed a unique econometric model for each of the considered calendar anomalies. The consistency of temporal effects is assessed for both the total sample and the five-year sub-periods.

\section{The Research Findings and the Interpretation}

The results of estimation of the Day-of-the-Week, Turn-of-the-Month, Month-of-the-Year, Quarter-of-theYear effect (Santa Claus rally), and the Quarter-End effects for the maximum period of each of the indexes are presented in Table 1.

The IBOV index of the Brazilian Stock Exchange (BM \& FBOVESPA) is characterized by the Weekend effect, the reverse Turn-of-the-Month effect, and the January effect.

In Russia, the Moscow Exchange MICEX index shows the Weekend effect, the reverse Turn-of-the-Month effect, the Santa Claus rally effect, and the reverse Quarter-End effect. The RTS index with regard to the MICEX index additionally shows the February effect, but it shows no Santa Claus rally effect.

The indexes of the two stock exchanges are also considered in India. The SENSEX index of the Bombay Stock Exchange (BSE) shows the Weekend and Turn-of-the-Month effects. The National Stock Exchange of India Limited (NSE) NIFTY index shows the reverse Wednesday effect, the Santa Claus rally effect, and the Quarter-End effect.

The Hong Kong Exchanges and Clearing Limited HSI index shows the Weekend, Santa Claus rally, and the reverse Quarter-End effects. The Shanghai Stock Exchange SHCOMP index shows the reverse Monday effect, Thursday effect, the reverse Turn-of-theMonth effect, and the reverse Quarter-End effect.
The Johannesburg Stock Exchange Limited TOP 40 index is the final one in the list to consider. This stock market shows all the studied temporal effects, namely the reverse effects of Thursday, Turn-of-theMonth, December effects, Santa Claus rally effects, and the reverse Quarter-End effects.

Based on the results obtained, Table 2 presents a roadmap of the BRICS countries' temporal effects. Due to transaction costs, deriving excess returns is unlikely, but ceteris paribus, it is necessary to use the findings when making trade decisions.

The information provided helps draw conclusions and develop an efficiency rating of the BRICS markets, taking into account the assumption about the dependence of the number of revealed temporal effects on the form of their efficiency:

- SENSEX index: Two temporal effects;

- IBOV, NIFTY, HSI, SHCOMP indexes: Three temporal effects per each;

- MICEX and RTS indexes: Four temporal effects per each;

- TOP 40 index: Five temporal effects.

\section{Conclusion}

The article achieved the main objective in the form of the results of the cross-country analysis of temporal effects on the stock markets of the BRICS nations. As well, it determines the forms of efficiency of the markets under consideration and raises an issue of opportunities to increase the investment portfolio yield.

The objects of the study were the Russian Exchange (PAO Moskovskaya Birzha - Moscow Exchange), Brazilian Stock Exchange (BM \& FBOVESPA), Bombay Stock Exchange Ltd. (BSE), National Stock Exchange of India Limited (NSE), Hong Kong Exchanges and Clearing Limited (HKEx), Shanghai Stock Exchange (SSE), and the Johannesburg Stock Exchange Limited (JSE Limited).

To achieve the objective, the results obtained earlier on the Day-of-the-Week, Turn-of-the-Month, Month-ofthe-Year, Quarter-of-the-Year effect (Santa Claus rally), and the Quarter-End effects were summarized. The possible causes of temporal effects were also considered. 
Based on the collected information and to estimate each of the five temporal effects, I have constructed a unique econometric model for each of the considered calendar anomalies. The consistency of temporal effects is assessed for both the total sample and the five-year sub-periods. In order to provide certain recommendations to increase the investment portfolio yield in each country, it is necessary to take into consideration the revealed temporal effects in each of them.

According to the efficient-market concept, all factors are taken into account in the stock prices, therefore deriving excess returns is impossible, and the pricing is completely described by the risk-yield relationship function.
However, the detected temporal effects testify to the inefficiency of stock markets and suggest the possibility to derive excess returns, considering the temporal effects when developing a trade strategy.

It should be borne in mind that a calendar anomaly can only be considered detected if it is consistent and capable of generating excess returns with consideration for transaction costs.

Thus, it is highly likely that an investment strategy based only on yield from temporal effects can not be built, due to transaction costs.

However, taking into account a particular calendar anomaly with all other things being equal will reduce the likelihood of a failed exchange purchase associated with a particular time period. 
Table 1

Evaluation of temporal effects of the BRICS countries

\begin{tabular}{|c|c|c|c|c|c|c|c|c|}
\hline Index & IBOV & RTS & MICEX & SENSEX & NIFTY & HSI & SHCOM & TOP 40 \\
\hline \multicolumn{9}{|c|}{ 1. Day-of-the-Week effect } \\
\hline Monday & -0.03 & $0.13^{\prime \prime \prime}$ & $0.13^{\prime \prime}$ & $0.06^{\prime \prime}$ & 0.05 & 0.02 & $0.07^{\circ}$ & $0.111^{\prime \prime}$ \\
\hline Tuesday & 0.05 & 0.04 & 0.06 & 0.01 & 0.01 & $0.06^{*}$ & 0.04 & 0.05 \\
\hline Wednesday & 0.22 & 0.05 & 0.03 & $0.08^{\prime \prime}$ & 0.18 & $0.11^{\cdots *}$ & $0.08^{\prime \prime}$ & 0.02 \\
\hline Thursday & $0.21^{* *}$ & $0.19^{\prime \prime \prime}$ & 0.16 & $0.06^{\circ}$ & 0.06 & $0.07^{* *}$ & $-0.07^{*}$ & $0.12^{\prime *}$ \\
\hline Friday & $0.27^{* *}$ & $0.15^{\cdots}$ & $0.2^{\cdots *}$ & $0.12^{\prime \prime \prime}$ & $0.09^{\prime \prime}$ & $0.15^{* \prime \prime}$ & $0.17^{* *}$ & 0.05 \\
\hline j & $0.15^{\cdots}$ & $0.1^{-1 *}$ & $0.03^{\prime \prime}$ & $0.1^{\cdots}$ & 0.08 & $0.09{ }^{\prime \prime \prime}$ & $0.077^{\prime \prime \prime}$ & 0.01 \\
\hline \multicolumn{9}{|c|}{ 2. Turn-of-the-Month effect } \\
\hline Const & $0.148^{\prime * *}$ & 0.069 & 0.045 & 0.068 & $0.083^{\circ}$ & 0,094 & $-0,034$ & $0,13^{\prime \prime \prime}$ \\
\hline 1 & $0.281^{* *}$ & $0.423^{* *+}$ & $0.443^{\cdots *}$ & $0.221^{* \prime}$ & $0.2002^{*}$ & $0.1102^{*}$ & $0.275^{\cdots}$ & $0.434^{\cdots \prime}$ \\
\hline 2 & $0.197^{* \prime}$ & $0.319^{* \prime}$ & $0.324^{\prime \prime}$ & 0.092 & 0.067 & $0.158^{* *+}$ & $0.216^{\prime \prime}$ & -0.1506 \\
\hline 3 & 0.034 & 0.103 & 0.047 & -0.021 & 0.006 & 0.041 & $0.192^{*}$ & -0.135 \\
\hline 4 & -0.025 & $0.304^{\prime \prime}$ & $0.274^{*}$ & 0.068 & 0.085 & 0.056 & 0.095 & -0.027 \\
\hline 5 & $0.183^{*}$ & 0.124 & 0.204 & -0.035 & -0.025 & -0.0502 & $0.214^{*}$ & -0.092 \\
\hline 6 & $-0.162^{\prime *}$ & 0.029 & 0.025 & -0.007 & -0.029 & -0.042 & 0.113 & -0.077 \\
\hline 7 & -0.051 & -0.006 & -0.066 & -0.012 & -0.129 & -0.063 & 0.031 & -0.025 \\
\hline 8 & -0.033 & $-0.286^{*}$ & $-0.327^{*}$ & 0.007 & -0.006 & -0.094 & 0.05 & -0.066 \\
\hline 9 & 0.023 & $0.265^{*}$ & $0.307^{* \prime}$ & -0.088 & -0.064 & -0.009 & 0.023 & -0.099 \\
\hline-9 & 0.028 & 0.072 & 0.024 & 0.052 & -0.021 & $-0.104^{\circ}$ & $0.168^{\circ}$ & 0.075 \\
\hline-8 & 0.029 & 0.082 & -0.026 & -0.033 & -0.008 & -0.017 & 0.106 & 0.039 \\
\hline-7 & 0.029 & -0.0007 & 0.038 & -0.099 & -0.085 & -0.004 & 0.0209 & -0.117 \\
\hline-6 & -0.024 & -0.0206 & -0.077 & $-0.139^{*}$ & $-0.181^{*}$ & -0.074 & 0.226 & $-0.177^{* \prime}$ \\
\hline-5 & $-0.166^{*}$ & 0.038 & 0.134 & 0.0106 & 0.032 & -0.0501 & -0.112 & $-0.172^{* \prime}$ \\
\hline-4 & $-0.1506^{\circ}$ & -0.122 & -0.105 & -0.002 & -0.011 & -0.053 & -0.012 & -0.139 \\
\hline-3 & 0.114 & -0.024 & 0.061 & -0.098 & -0.127 & -0.015 & $0.176^{\prime \prime}$ & -0.152 \\
\hline-2 & 0.076 & -0.035 & 0.117 & 0.076 & 0.134 & 0.005 & 0.023 & -0.1108 \\
\hline-1 & 0.079 & 0.121 & $0.254^{\circ}$ & $0.261^{* *}$ & 0.243 & $0.189^{\ldots *}$ & $0.189^{* \prime}$ & -0.084 \\
\hline \multicolumn{9}{|c|}{ 3. Month-of-the-Year effect } \\
\hline January & $0.287^{\cdots+\cdots}$ & $0.161^{*}$ & $0.186^{*}$ & 0.019 & 0.007 & 0.14 & 0.096 & 0.07 \\
\hline February & $0.253^{\cdots *}$ & $0.347^{\cdots \cdots}$ & $0.376 \cdots$ & 0.066 & 0.065 & $0.097^{* \prime}$ & $0.152^{*}$ & 0.078 \\
\hline March & $0.15^{\cdots *}$ & 0.035 & 0.013 & 0.024 & 0.0601 & -0.049 & -0.001 & 0.007 \\
\hline April & $0.227^{\cdots+\cdots}$ & 0.102 & 0.063 & 0.044 & 0.015 & $0.1608^{* \prime}$ & 0.049 & 0.015 \\
\hline May & $0.228^{\prime \prime *}$ & 0.007 & 0.032 & 0.087 & 0.098 & $0.097^{*}$ & 0.089 & 0.079 \\
\hline June & 0.058 & 0.148 & 0.103 & 0.154 & $0.153^{\cdots}$ & 0.042 & 0.007 & -0.011 \\
\hline July & $0.152^{\cdots-}$ & 0.078 & 0.037 & 0.058 & 0.015 & $0.162^{* *}$ & 0.0104 & $0.125^{*}$ \\
\hline August & $0.2^{* *}$ & $0.154^{*}$ & 0.111 & 0.081 & 0.059 & -0.011 & 0.058 & 0.087 \\
\hline September & $0.223^{\prime \prime \prime}$ & 0.10005 & 0.109 & $0.15^{\prime \prime}$ & $0.158^{*}$ & 0.0405 & -0.023 & $0.126^{\circ}$ \\
\hline October & 0.042 & $0.202^{\circ}$ & $0.235^{\cdots}$ & 0.042 & 0.088 & $0.205^{* \prime}$ & $0.1101^{\circ}$ & $0.122^{*}$ \\
\hline November & 0.032 & 0.071 & 0.073 & $0.107^{*}$ & $0.168^{\prime \prime \prime}$ & $0.112^{* *}$ & $0.127^{*}$ & 0.07 \\
\hline December & $0.169^{\prime \prime \prime}$ & $0.165^{\circ}$ & 0.161 & $0.119^{*}$ & $0.16^{\prime \prime \prime}$ & $0.113^{* *}$ & $0.137^{* \prime}$ & $0.156^{\prime \prime}$ \\
\hline
\end{tabular}

${ }^{*}$ Significance level: $10 \%$

${ }^{* *}$ Significance level: $5 \%$

*** Significance level: $1 \%$.

Source:Authoring 
Table 2

The roadmap of time effects of the BRICS countries

\begin{tabular}{|c|c|c|c|c|}
\hline Index & IBOV & MICEX & RTS & SENSEX \\
\hline Day-of-the-Week effect & $\begin{array}{l}\text { - Monday effect (Not observed } \\
\text { in recent years); } \\
\text { - Weekend effect }\end{array}$ & Weekend effect & Weekend effect & Weekend effect \\
\hline Turn-of-the-Month effect & $\begin{array}{l}\text { Reverse Turn-of-the-Month } \\
\text { effect }\end{array}$ & $\begin{array}{l}\text { Reverse Turn-of-the- } \\
\text { Month effect }\end{array}$ & $\begin{array}{l}\text { Reverse Turn-of-the- } \\
\text { Month effect }\end{array}$ & Turn-of-the-Month effect \\
\hline Month-of-the-Year effect & January effect & Not observed & February effect & Not observed \\
\hline $\begin{array}{l}\text { Quarter-of-the-Year effect } \\
\text { (Santa Claus rally effect) }\end{array}$ & Not observed & Santa Claus rally effect & Not observed & Not observed \\
\hline Quarter-End effect & Not observed & $\begin{array}{l}\text { Reverse Quarter-End } \\
\text { effect }\end{array}$ & $\begin{array}{l}\text { Reverse Quarter-End } \\
\text { effect }\end{array}$ & Not observed \\
\hline Total... & 3 & 4 & 4 & 2 \\
\hline \multicolumn{5}{|l|}{ Continued } \\
\hline Index & NIFTY & HSI & SHCOM & TOP 40 \\
\hline Day-of-the-Week effect & Reverse Wednesday effect & Weekend effect & $\begin{array}{l}\text { - Reverse Monday } \\
\text { effect; } \\
\text { - Thursday effect }\end{array}$ & Reverse Thursday effect \\
\hline Turn-of-the-Month effect & Not observed & Not observed & $\begin{array}{l}\text { Reverse Turn-of-the- } \\
\text { Month effect }\end{array}$ & $\begin{array}{l}\text { Reverse Turn-of-the- } \\
\text { Month effect }\end{array}$ \\
\hline Month-of-the-Year effect & Not observed & Not observed & Not observed & December effect \\
\hline $\begin{array}{l}\text { Quarter-of-the-Year effect } \\
\text { (Santa Claus rally effect) }\end{array}$ & Santa Claus rally effect & Santa Claus rally effect & Not observed & Santa Claus rally effect \\
\hline Quarter-End effect & Quarter-End effect & $\begin{array}{l}\text { Reverse Quarter-End } \\
\text { effect }\end{array}$ & $\begin{array}{l}\text { Reverse Quarter-End } \\
\text { effect }\end{array}$ & $\begin{array}{l}\text { Reverse Quarter-End } \\
\text { effect }\end{array}$ \\
\hline Total... & 3 & 3 & 3 & 5 \\
\hline
\end{tabular}

Source:Authoring 


\section{Figure 1}

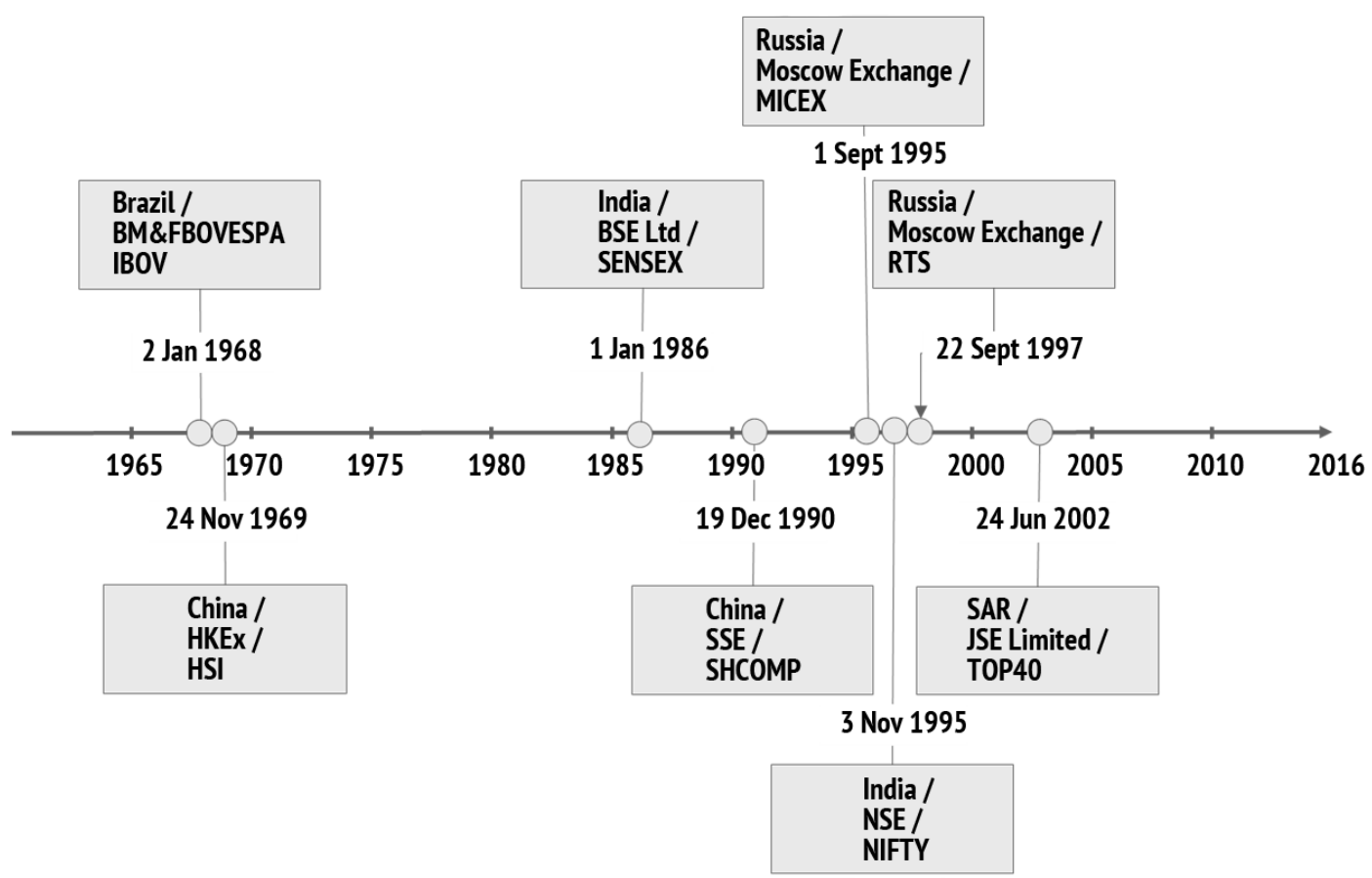

Source:Authoring

\section{References}

1. Fama E.F. The Behavior of Stock-Market Prices. The Journal of Business, 1965, vol. 38, iss. 1, pp. 34-105. URL: http://citeseerx.ist.psu.edu/viewdoc/download?doi=10.1.1.365.9468\&rep=rep1\&type=pdf

2. Davis M.H.A. Louis Bachelier's "Theory of Speculation". URL: https://f-origin.hypotheses.org/wp-content/blogs.dir/1596/files/2014/12/Mark-Davis-Talk.pdf

3. French K.R. Stock Returns and the Weekend Effect. Journal of Financial Economics, 1980, vol. 8, iss. 1, pp. 55-69. URL: https://doi.org/10.1016/0304-405X(80)90021-5

4. Rogalski R.J. New Findings Regarding Day-of-the-Week Returns over Trading and Non-Trading Periods: A Note. The Journal of Finance, 1984, vol. 39, iss. 5, pp. 1603-1614. URL: https://doi.org/10.2307/2327747

5. Harris L. A Transaction Data Study of Weekly and Intradaily Patterns in Stock Returns. Journal of Financial Economics, 1986, vol. 16, iss. 1, pp. 99-117. URL: https://doi.org/10.1016/0304-405X(86)90044-9

6. Ariel R.A. A Monthly Effect in Stock Returns. Journal of Financial Economics, 1987, vol. 18, iss. 1, pp. 161-174. URL: https://doi.org/10.1016/0304-405X(87)90066-3

7. Lakonishok J., Smidt S. Are Seasonal Anomalies Real? A Ninety-Year Perspective. Review of Financial Studies, Society for Financial Studies, 1988, vol. 1, iss. 4, pp. 403-425.

8. Pettengill G.N., Jordan B.D. A Comprehensive Examination of Volume Effects and Seasonality in Daily Security Return. The Journal of Financial Research, 1988, vol. 11, iss. 1, pp. 57-70. URL: https://doi.org/10.1111/j.1475-6803.1988.tb00066.x 
9. Liano K., Lindley J.T. An Analysis of the Weekend Effect within the Monthly Effect. Review of Quantitative Finance and Accounting, 1995, vol. 5, iss. 4, pp. 419-426.

10. Keef S.P., Roush M.L. Day-of-the-Week Effects in the Pre-holiday Returns of the Standard and Poor's 500 Stock Index. Applied Financial Economics, 2005, vol. 15, iss. 2, pp. 107-119. URL: https://doi.org/10.1080/0960310042000293164

11. Jaffe J., Westerfield R. The Week-End Effect in Common Stock Returns: The International Evidence. The Journal of Finance, 1985, vol. 40, iss. 2, pp. 433-454. URL: https://doi.org/10.2307/2327894

12. Aggarwal R., Rivoli P. Seasonal and Day-of-the-Week Effects in Four Emerging Stock Markets. The Financial Review, 1989, vol. 24, iss. 4, pp. 541-550.

13. Marrett G.E., Worthington A. The Day-of-the-Week Effect in the Australian Stock Market: An Empirical Note on the Market, Industry and Small Cap Impacts. International Journal of Business and Management, 2008, vol. 3, iss. 1, pp. 3-8.

URL: https://research-repository.griffith.edu.au/bitstream/handle/10072/22336/50755_1.pdf;sequence=1

14. Mbululu D., Chipeta C. Day of the Week Effect: Evidence from Nine Economic Sectors of JSE. Investment Analysis Journal, 2012, vol. 41, iss. 75, pp. 55-65.

15. Kurashinov M. ["Wednesday effect", or The national trait of the Russian securities market]. Rynok tsennykh bumag = Securities Market, 2004, no. 24, pp. 13-15. (In Russ.) URL: http://old.rcb.ru/archive/articles.asp?id=4550

16. McGowan C.B. Jr., Ibrihim I. An Analysis of the Day-of-the-Week Effect in the Russian Stock Market. International Business \& Economics Research, 2009, vol. 8, iss. 9, pp. 25-30.

URL: https://doi.org/10.19030/iber.v8i9.3165

17. Singleton J.C., Wingender J.R. The Nonparallel Weekend Effect in the Stock and Bond Markets.

The Journal of Financial Research, 1994, vol. 17, iss. 4, pp. 531-538.

URL: https://doi.org/10.1111/j.1475-6803.1994.tb00163.x

18. Thatcher J.S., Blenman L.P. Synthetic Trades and Calendar Day Patterns: The Case of the Dollar/Sterling Markets. The Financial Review, 2001, May, vol. 36, iss. 2, pp. 177-200. Available at SSRN: https://ssrn.com/abstract $=274386$

19. Liano K., Huang G.-C., Gup B.E. A Twist on the Monday Effect in Stock Returns: A Note. Journal of Economics and Business, 1993, vol. 45, iss. 1, pp. 61-67. URL: https://doi.org/10.1016/0148-6195(93)90006-A

20. Johnston E.T., Kracaw W.A., McConnell J.J. Day-of-the-Week Effects in Financial Futures: An Analysis of GNMA, T-Bond, T-Note, and T-Bill Contracts. The Journal of Financial and Quantitative Analysis, 1991, vol. 26, iss. 1, pp. 23-44. URL: https://doi.org/10.2307/2331241

21. Redman A.L., Manakyan H., Liano K. Real Estate Investment Trusts and Calendar Anomalies. Journal of Real Estate Research, 1997, vol. 14, iss. 1/2, pp. 19-28.

URL: http://pages.jh.edu/jrer/papers/pdf/past/vol14n01/v14p019.pdf

22. Sias R.W., Starks L.T. The Day-of-the-Week Anomaly: The Role of Institutional Investors. Financial Analysts Journal, 1995, vol. 51, iss. 3, pp. 58-67. Stable URL: http://www.jstor.org/stable/4479847

23. Abraham A., Ikenberry D.L. The Individual Investor and the Weekend Effect. The Journal of Financial and Quantitative Analysis, 1994, vol. 29, iss. 2, pp. 263-277. URL: https://doi.org/10.2307/2331225 
24. Damodaran A. The Weekend Effect in Information Releases: A Study of Earnings and Dividend Announcements. The Review of Financial Studies, 1989, vol. 2, iss. 4, pp. 607-623. URL: https://doi.org/10.1093/rfs/2.4.607

25. Pettengill G.N., Wingender J.R. Jr., Kohli R. Arbitrage, Institutional Investors, and the Monday Effect. Quarterly Journal of Business and Economics, 2003, vol. 42, iss. 3/4, pp. 49-63.

URL: http://www.academia.edu/21127832/Arbitrage_Institutional_Investors_and_the_Monday_Effect

26. 26. Pettengill G.N. An Experimental Study of the 'Blue Monday' Hypothesis. The Journal of Socio-Economics, 1993, vol. 22, iss. 3, pp. 241-257. URL: https://doi.org/10.1016/1053-5357(93)90011-9

27. Chow E.H., Hsiao P., Solt M.E. Trading Returns for the Weekend Effect Using Intraday Data. Journal of Business Finance and Accounting, 1997, vol. 24, iss. 3, pp. 425-444.

28. Miller E.M., Prather L.J., Mazumder M.I. Day-of-the-Week Effects Among Mutual Funds. Quarterly Journal of Business and Economics, 2003, vol. 42, iss. 3/4, pp. 113-128.

Stable URL: http://www.jstor.org/stable/23292843

29. Fedorova E.A., Gilenko E.V. [Comparative analysis of the approaches to estimation of calendar effects in a financial market]. Audit i finansovyi analiz = Audit and Financial Analysis, 2008, no. 5, pp. 184-189. URL: http://www.auditfin.com/fin/2008/5/Fedorova/Fedorova\%20.pdf (In Russ.)

\section{Conflict-of-interest notification}

I, the author of this article, bindingly and explicitly declare of the partial and total lack of actual or potential conflict of interest with any other third party whatsoever, which may arise as a result of the publication of this article. This statement relates to the study, data collection and interpretation, writing and preparation of the article, and the decision to submit the manuscript for publication. 